Max-Planck-Institut für demografische Forschung

Max Planck Institute for Demographic Research

Konrad-Zuse-Strasse 1 - D-18057 Rostock - GERMANY

Tel +49 (0) 3812081 - 0; Fax +49 (0) 3812081 - 202;

http://www.demogr.mpg.de

MPIDR TECHNICAL REPORT 2015-003

MAY 2015

\title{
Fertility Assessment with the \\ Own-Children Method: \\ A Validation with Data from the \\ German Mikrozensus
}

Sandra Krapf
Michaela Kreyenfeld (kreyenfeld@demogr.mpg.de)

For additional material see www.demogr.mpg.de/tr/

(C) Copyright is held by the authors.

Technical reports of the Max Planck Institute for Demographic Research receive only limited review. Views or opinions expressed in technical reports are attributable to the authors and do not necessarily reflect those of the Institute. 


\title{
Fertility Assessment with the Own-Children Method:
}

\section{A Validation with Data from the German Mikrozensus}

\author{
Sandra Krapf and Michaela Kreyenfeld
}

\begin{abstract}
The German Mikrozensus is a data set that is frequently used to study fertility behavior. With its large sample size, the dataset also offers the opportunity to investigate childbearing among population subgroups, such as particular migrant groups. Because birth histories are not surveyed in the Mikrozensus, scholars have frequently employed the Own-Children Method (OCM) to generate fertility schedules from this data. The OCM draws on information on the number and ages of the co-residential children in order to estimate the fertility schedule of women. It is clear that this method leads to an underestimation of fertility, because children do not necessarily live with their biological mother. It is also clear that the bias is stronger for older women, because children may have left parental home. In the past, it was not possible to assess the bias. With the Mikrozensus 2008, we are able to validate the OCM by relying on respondent's own report on the total number of children. We furthermore examine whether the OCM leads to worse estimates for migrants and non-migrants. The results show that the OCM provides reasonable fertility estimates for women in western Germany up to age 40, irrespective of migrant background. For eastern Germany, there is a stronger bias at later ages than in western Germany. This relates to the early age at childbirth in this region and the more diverse family structures.
\end{abstract}

Keywords: Fertility, Migration, Own-Children-Method, Germany 


\section{Introduction}

According to OECD-statistics, Germany had the second largest immigrant inflow among the OECD countries in 2012 after the United States (OECD 2014). In 2013, the population with a migrant background residing in Germany amounted to 20.5 percent (Bundesamt für Migration und Flüchtlinge 2015). Migration is an important component of population composition because of two reasons: First, migrant groups might differ in their socio-demographic structure from the non-migrant population. Second, migrants and their descendants might follow different fertility patterns than natives. Many studies indicate that the total fertility rate (TFR) of immigrant women exceeds the one of native women in European countries (see Sobotka 2008 for an overview). In order to improve our understanding of the fertility patterns among different migrant groups, it is important to investigate the different migrants groups separately. Many of the data sets that are commonly used to examine migrant fertility, such as the German Socio-Economic Panel (SOEP) or the Generations and Gender Survey (GGS), contain too few cases to analyze the behavior of different migrant groups separately or to focus on fertility of recent migrants more specifically. The German GGS, for example, oversamples Turkish migrants, but does not contain sufficient case numbers of other migrant groups. The SOEP oversamples other migrant groups, such as Ethnic Germans, but sample sizes are still too low to study the behavior of these groups in much detail.

The Mikrozensus overcomes many of the shortcomings of previous datasets. It surveys one percent of households in Germany and, thus, contains sufficient large sample sizes. It also contains migration specific variables, such as time since migration and country of origin. With its large sample size and, by now, fairly detailed migrant specific background information, the Mikrozensus opens up new potential to investigate the behavior of recent migrants in Germany (for analysis of labor market behavior, see for example Herwig and Konietzka 2012). However, some caveats remain in the analysis of demographic behavior with the Mikrozensus. The Mikrozensus is strong when it comes to cross-sectional information, but provides only very little retrospective information. Birth histories have never been surveyed in the Mikrozensus. Scholars have overcome this shortcoming by using the Own-Children Method (OCM) (see Kreyenfeld, Schmidtke and Zühlke 2009 for a collection of studies using the Mikrozensus). The OCM draws on information on the number and ages of the co-residential children in order to estimate the fertility schedule of women. It is clear that this Own-Children Method leads to an underestimation of fertility, because children do not necessarily live with their biological mother. It is also clear that the bias is stronger for older women, because children may have already left parental home. In the past, it was 
not possible to assess the bias of the OCM. With the Mikrozensus 2008, which included information on the total number of children born, we are able to do so. ${ }^{1}$

In this report, we explore the potential and limitations of the Mikrozensus to study fertility behavior. We provide separate estimates for western and eastern Germany. Since our particular focus is on the migrant behavior, we also provide estimates by migrant background. We focus on the two largest migrant groups in Germany: Ethnic Germans (Aussiedler) and migrants from Turkey. Aussiedler are migrants with German roots who had been living in Eastern European countries and who migrated to Germany in particular during the 1990s. With 3.9 percent of the total population, they make up the largest share of people with a (direct) migrant background residing in Germany today (Bundesamt für Migration und Flüchtlinge 2014). Mass migration from Turkey started in the 1960s as part of the labor migration to Germany. Today, migration from Turkey is usually related to family reunion or family formation and with 3.7 percent (Bundesamt für Migration und Flüchtlinge 2014), people of Turkish origin are the second largest group of migrants living in Germany. Both groups are an interesting study population: Migrants from Turkey are originated in a high fertility country. By contrast, Aussiedler (as other migrants from Eastern European countries) originate from low fertility settings. We show that up to age 40 , the OCM provides reliable fertility histories for non-migrant women living in western Germany, women of Turkish origin and Aussiedler. Also for eastern Germany, OCM provides reliable results. However, here the "cut-off age" is already at 39 years. After that age, the estimates from the OCM get unreliable. This is explained by the early age at childbearing in eastern Germany, but is caused by the diverse family structures in this part of Germany.

\section{The Own-Children Method}

The OCM is a common technique for reconstructing women's fertility behavior in the absence of retrospective birth histories. It is often used with historical census or microcensus data that include household information, but no retrospective fertility histories (Desplanques 1994). High child mortality used to distort estimates from the OCM with historical data. A conundrum was also that family units were often difficult to identify, when the extended family lived in one household unit. The OCM used on contemporary census or microcensus data is less prone to such biases. First of all, in post-modern societies, child mortality is very low and should not produce serious distortion of the estimates.

1 The total number of children is surveyed every four years starting with the Mikrozensus 2008. At the time that this report was written, data from the Mikrozensus 2012 were not available yet as a scientific-use-file. 
Secondly, the family unit can be identified in most census and micro-census data much easier than this was the case with historical data. In the German Mikrozensus, the relationship of the head of household with all other household members is surveyed (DESTATIS 2009a; Lengerer, Janßen and Bohr 2007). Albeit that some inconsistencies remain unresolved, it is generally possible to generate a consistent family identifier and thus to connect co-residential children and parents in this data set. However, some caveats remain in applying OCM to contemporary data. Most importantly, estimates may be unreliable because children might have left the respondent's home. The reason may be that they formed an independent household. However, separation and divorce of the parents are other factors why children may not reside with their biological parents. Our study is restricted to female respondents only. Because children commonly reside with their mothers after separation and divorce, the bias may not be grave. Nevertheless, there is substantial uncertainty in the research community of whether and to which age it is possible to use the OCM to estimate the fertility schedule with contemporary census or micro-census data. Some researchers have limited their sample to women up to age 38 (Kreyenfeld 2009), age 45 years (Adsera and Ferrer 2014) while others analyzed fertility of women up to age 49 (Wirth and Dümmler 2013). Prior studies were unable to validate their "cut-off age" in a reliable way. In our study, we overcome this shortcoming, because the Mikrozensus of the year 2008 surveys the number of children born to a woman. In this way, we can assess the appropriate "cut-off age" until we may rely on the OCM to generate the fertility schedule of a woman.

\section{Data and method}

Our analyses are based on data from the Scientific-Use-File of the German Mikrozensus of the year 2008. The Mikrozensus is based on a one-percent sample of all households in Germany; the ScientificUse-File is a 70 percent subsample of it (Boehle and Schimpl-Neimanns 2010). Since 2005, it includes detailed migrant specific information which allows us to identify Aussiedler. Also year of (last) migration to Germany is surveyed in this dataset. The great advantage of the Mikrozensus is its large sample size, which enables us to focus more specifically on the behavior of subgroups of migrants, such as Aussiedler and Turkish migrants. A great advantage of the Mikrozensus is furthermore the low unit non-response; in the survey wave of 2008 it was about 3 percent (DESTATIS 2009c). Nonresponse is of minor relevance in the Mikrozensus because participation is obligatory and respondents are required by law to submit information. Although non-response is higher among those households with a non-German head of household than among German households (Afentakis and Bihler 2005) the number of migrants is still 
large enough for separate analyses. This is of particular importance for our study, because other social science surveys commonly undercover migrants in their samples.

The total number of female respondents in the SUF Mikrozensus 2008 was 211,081. For our investigation, we limit the analysis to women aged $18-45 .^{2}$ We exclude those under age 18 and those aged 46 and older. We furthermore exclude migrants who are neither originated from Turkey and who neither migrated as Aussiedler. Based on this sample, we group our study population into four groups:

- Western Germans: Respondents living in western Germany at time of interview who do not have a migrant background

- Eastern Germans: Respondents living in eastern Germany at time of interview who do not have a migrant background

- Aussiedler: Respondents who have migrated as ethnic German repatriates from the states of the former Soviet Union and other former eastern bloc states to Germany. They might reside in both eastern or western Germany (including Berlin).

- Turkish migrants: Respondents who have migrated from Turkey to Germany. They might reside in both eastern or western Germany (including Berlin).

Our final sample consists of 76,595 female respondents. The number of respondents in each subsample differs considerably (western Germany: 54,973; eastern Germany: 16,265; Turkish migrants: 2,164; Aussiedler: 3,193; see also appendix).

Our analytical strategy is as follows: We compare the reported number of children with the number of children generated by the OCM. The smaller the difference between both values, the more accurate we assume is the OCM. We perform this comparison by single age groups. In general, one would assume that respondent's report on the total number of children is a reliable benchmark, however, it needs mentioning here that non-response on this item was rather high in the Mikrozensus. About 13 percent of the respondents failed to provide valid information on the number of their children. The German Statistical Office imputed this missing information and we had, thus, to rely on these imputed value for our analysis (DESTATIS 2009b).

2 Moreover, we did not consider women living in some form of institutional accommodation and those who were interviewed in a year different than in 2008. 


\section{Results}

Figure 1 displays the results from our investigation. The solid lines refer to the average number of children living in the household which is calculated by women's age using OCM. The dashed lines indicate the average reported number of births. The pattern is very smooth for the western German sample. For the other groups, the average number of children fluctuates more because of smaller sample sizes. Despite these variations, there is some commonality. Up to age 35 , the OCM and the estimates from the respondent's reports on the number of children generate almost identical results. However, with growing age, the curves start to diverge. At age 40 the OCM leads to a somewhat lower estimated number of children for western Germans (difference 0.09) compared to the reported number of children. The underestimation is larger for eastern Germans (0.17), Turkish migrants (0.14) and Aussiedler (0.15). By age 46, in western Germany the OCM underestimates the reported number of births by 0.38 , in eastern Germany by 0.84 , among Turkish migrants and Aussiedler by 0.68 (see also Table 1 and Table 2 in the appendix). The large divergence in eastern Germany might occur due to the lower age at childbearing (Goldstein and Kreyenfeld 2011) and the lower age at leaving parental home (Konietzka and Tatjes 2014) in this part of the country .

\section{Conclusions}

Scholars have used the Own-Children Method (OCM) in order to study fertility dynamics with data from the German Mikrozensus. This report has validated the OCM by drawing on respondent's report on the total number of live births. This information was surveyed for the first time in the Mikrozensus 2008. We were particularly interested in the question whether the OCM provided less reliable results for the two most important migrant populations in Germany, namely Turkish and ethnic German migrants (Aussiedler). The main result from this comparison is that there are no major differences in the validity of the results by population subgroups. For all groups, differences increase after age 35 between the OCM and respondent's reports on the total number of children. If we accept a (arguably arbitrary) difference of 0.15 children as an acceptable difference between the two fertility measurements, we conclude that for western Germans, Turkish migrants and Aussiedler, the underestimation of the OwnChildren Method is acceptable up to age 40. For eastern German women, the OCM leads to acceptable fertility estimation for respondents up to 39 years. 
Figure 1: Average number of children by age of women. Comparison between the Own-Children Method and the reported number of children.
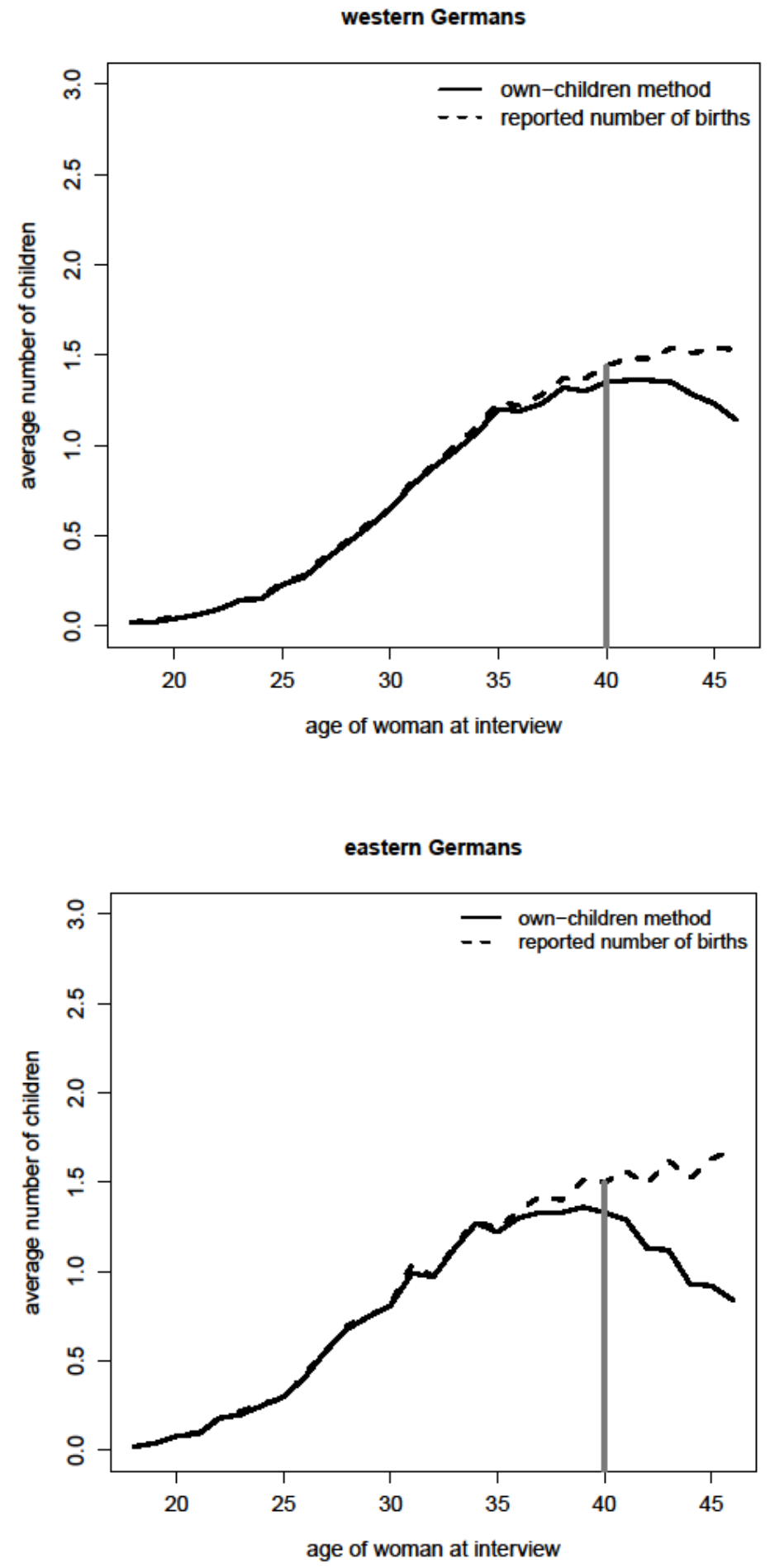
Figure 1 (continued): Average number of children by age of women. Comparison between the OwnChildren Method and the reported number of children .
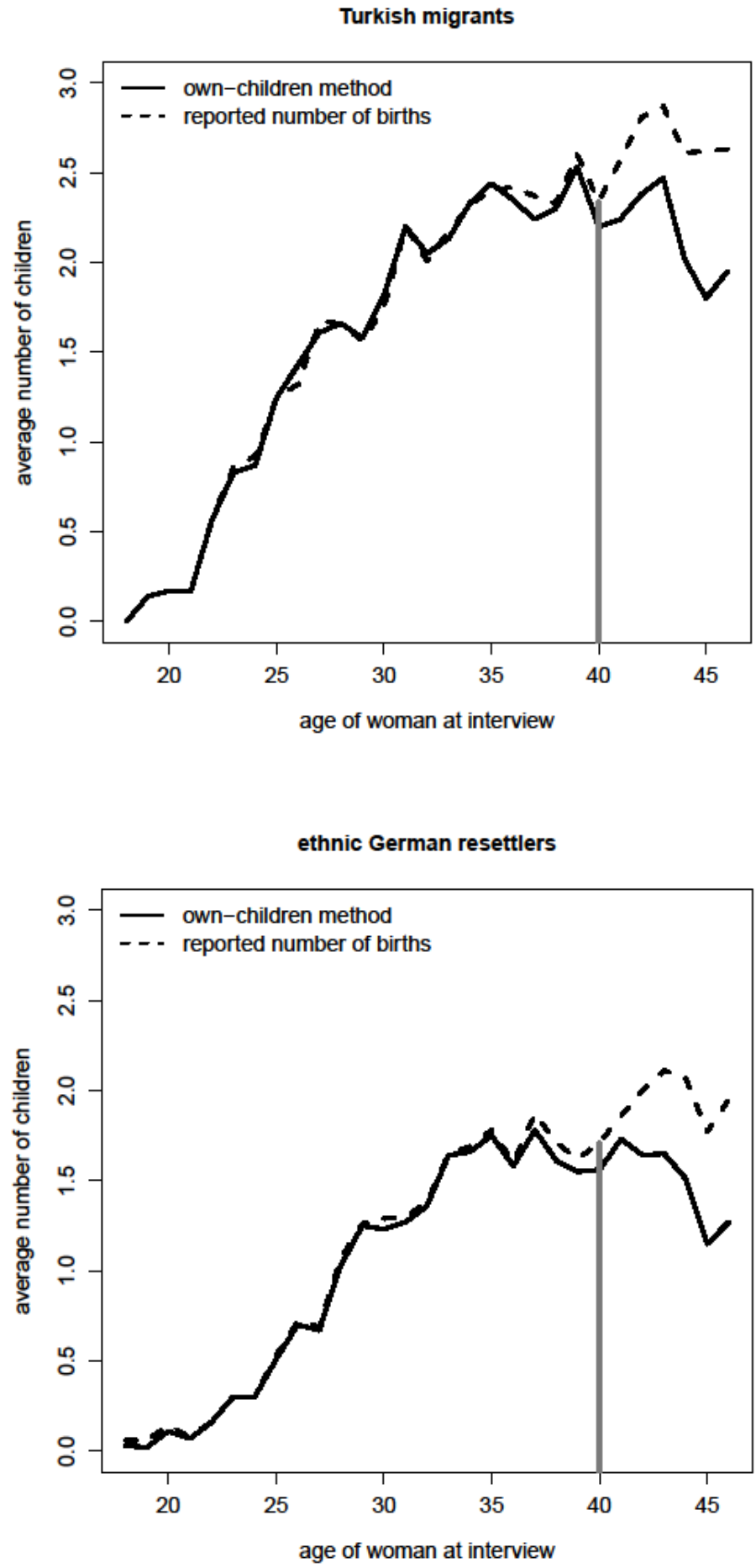

Source: Mikrozensus 2008. Authors' own calculations. 


\section{Acknowledgments}

The research leading to these results has received funding from the European Union's Seventh Framework Programme (FP7/2007-2013) under grant agreement no. 320116 for the research project FamiliesAndSocieties. 


\section{References}

Adsera, A.and A. Ferrer. 2014. "Factors influencing the fertility choices of child immigrants in Canada." Population Studies 68(1):65-79.

Afentakis, A.and W. Bihler. 2005. "Das Hochrechnungsverfahren beim unterjährigen Mikrozensus ab 2005." Wirtschaft und Statistik 10/2005.

Boehle, M.and B. Schimpl-Neimanns. 2010. "Mikorzensus Scientific Use File 2008: Dokumentation und Datenaufbereitung. Technical Reports 2010/13." GESIS - Leibniz-Institut für Sozialwissenschaften.

Bundesamt für Migration und Flüchtlinge. 2014. "Migrationsbericht 2012." Nürnberg: BAMF.

-. 2015. "Migrationsbericht des Bundesamtes für Migration und Flüchtlinge im Auftrag der Bundesregierung (Migrationsbericht 2013)." Nürnberg: BAMF.

Desplanques, G. 1994. "Measuring Fertility Differentials from Census Information Alone." Population: An English Selection 6(ArticleType: research-article / Full publication date: 1994 / Copyright (C) 1994 Institut National d'Études Démographiques):23-33.

DESTATIS. 2009a. Bevölkerung und Erwerbstätigkeit. Haushalte und Familien. Ergebnisse des Mikrozensus 2008. Wiesbaden: Statistisches Bundesamt.

-. 2009b. "Methodeninformation. Imputation von Werten bei fehlenden Angaben zur Mutterschaft und zur Zahl der geborenen Kinder im Mikrozensus 2008." Wiesbaden: Statistisches Bundesamt.

-. 2009c. Mikrozensus 2008. Qualitätsbericht. Wiesbaden: Statistisches Bundesamt.

Goldstein, J.and M. Kreyenfeld. 2011. "Has East Germany Overtaken West Germany? Recent Trends in Order-Specific Fertility." Population and Development Review 37(3):453-472.

Herwig, A.and D. Konietzka. 2012. "Zwischen Integration und Ausschluss. Die Klassenpositionen von Migranten im Zeit- und Generationenvergleich." Zeitschrift für Soziologie 41(4):295-315.

Konietzka, D.and A. Tatjes. 2014. "Two steps of union formation: first intimate relationships and first coresidential unions in the life courses of the German Cohorts 1971-1973 and 1981-1983." Journal of Youth Studies 17(8):1077-1096.

Kreyenfeld, M. 2009. "Das zweite Kind in Ostdeutschland: Aufschub oder Verzicht?" in Die Bevölkerung in Ost- und Westdeutschland. Demographische, gesellschaftliche und wirtschaftliche Entwicklung seit der Wende, edited by I. Cassens, M. Luy, and R. Scholz. Wiesbaden: VS Research.

Kreyenfeld, M., K. Schmidtke, and S. Zühlke. 2009. "Eignet sich das Mikrozensus-Panel für familiensoziologische Fragestellungen? Untersuchung am Beispiel der Frage nach den ökonomischen Determinanten der Familiengründung." Zeitschrift für Familienforschung 21(3). 
Lengerer, A., A. Janßen, and J. Bohr. 2007. "Familiensoziologische Analysepotenziale des Mikrozensus " Zeitschrift für Familienforschung 19(2):186-209.

OECD. 2014. "International Migration Outlook 2014." OECD Publishing.

Sobotka, T. 2008. "Overview Chapter 7: The rising importance of migrants for childbearing in Europe." Demographic Research S7(9):225-248.

Wirth, H.and K. Dümmler. 2013. "Zunehmende Tendenz zu späteren Geburten und Kinderlosigkeit bei Akademikerinnen." Informationsdienst Soziale Indikatoren: ISI Sonderausgabe November 27-31. 


\section{Appendix}

Table 1: $\quad$ Average number of children and number of cases in each age group for different groups. Mikrozensus 2008.

\begin{tabular}{|c|c|c|c|c|c|c|c|c|}
\hline \multirow[b]{2}{*}{$\begin{array}{l}\text { age of } \\
\text { woman } \\
\text { in years }\end{array}$} & \multicolumn{4}{|c|}{ western German women } & \multicolumn{4}{|c|}{ eastern German women } \\
\hline & $\begin{array}{l}\text { Own- } \\
\text { Children } \\
\text { Method }\end{array}$ & $\begin{array}{l}\text { reported } \\
\text { number of } \\
\text { kids }\end{array}$ & difference & $\mathrm{n}$ & $\begin{array}{l}\text { Own- } \\
\text { Children } \\
\text { Method }\end{array}$ & $\begin{array}{l}\text { reported } \\
\text { number } \\
\text { of kids }\end{array}$ & difference & $\mathrm{n}$ \\
\hline 18 & 0.02 & 0.02 & 0.00 & 1,696 & 0.02 & 0.02 & 0.00 & 550 \\
\hline 19 & 0.02 & 0.03 & -0.01 & 1,707 & 0.04 & 0.04 & 0.00 & 533 \\
\hline 20 & 0.04 & 0.05 & -0.01 & 1,799 & 0.08 & 0.08 & 0.00 & 582 \\
\hline 21 & 0.06 & 0.06 & 0.00 & 1,627 & 0.09 & 0.10 & -0.01 & 550 \\
\hline 22 & 0.09 & 0.09 & 0.00 & 1,621 & 0.18 & 0.18 & 0.00 & 587 \\
\hline 23 & 0.14 & 0.14 & 0.00 & 1,586 & 0.20 & 0.22 & -0.02 & 534 \\
\hline 24 & 0.15 & 0.16 & -0.01 & 1,538 & 0.25 & 0.26 & -0.01 & 503 \\
\hline 25 & 0.23 & 0.24 & -0.01 & 1,642 & 0.30 & 0.29 & 0.01 & 489 \\
\hline 26 & 0.27 & 0.28 & -0.01 & 1,594 & 0.41 & 0.43 & -0.02 & 529 \\
\hline 27 & 0.37 & 0.39 & -0.02 & 1,607 & 0.56 & 0.56 & 0.00 & 499 \\
\hline 28 & 0.46 & 0.47 & -0.01 & 1,554 & 0.68 & 0.70 & -0.02 & 513 \\
\hline 29 & 0.55 & 0.57 & -0.02 & 1,451 & 0.75 & 0.75 & 0.00 & 456 \\
\hline 30 & 0.65 & 0.65 & 0.00 & 1,470 & 0.81 & 0.82 & -0.01 & 470 \\
\hline 31 & 0.78 & 0.80 & -0.02 & 1,415 & 0.99 & 1.04 & -0.05 & 398 \\
\hline 32 & 0.88 & 0.89 & -0.01 & 1,470 & 0.97 & 0.97 & 0.00 & 400 \\
\hline 33 & 0.97 & 1.00 & -0.03 & 1,434 & 1.13 & 1.15 & -0.02 & 409 \\
\hline 34 & 1.07 & 1.10 & -0.03 & 1,525 & 1.27 & 1.28 & -0.01 & 433 \\
\hline 35 & 1.20 & 1.24 & -0.04 & 1,622 & 1.22 & 1.24 & -0.02 & 451 \\
\hline 36 & 1.19 & 1.22 & -0.03 & 1,878 & 1.30 & 1.34 & -0.04 & 524 \\
\hline 37 & 1.23 & 1.28 & -0.05 & 1,943 & 1.33 & 1.42 & -0.09 & 585 \\
\hline 38 & 1.32 & 1.37 & -0.05 & 2,136 & 1.33 & 1.40 & -0.07 & 600 \\
\hline 39 & 1.30 & 1.37 & -0.07 & 2,409 & 1.36 & 1.51 & -0.15 & 573 \\
\hline 40 & 1.35 & 1.44 & -0.09 & 2,576 & 1.33 & 1.50 & -0.17 & 632 \\
\hline 41 & 1.36 & 1.48 & -0.12 & 2,633 & 1.29 & 1.56 & -0.27 & 691 \\
\hline 42 & 1.36 & 1.48 & -0.12 & 2,638 & 1.13 & 1.49 & -0.36 & 735 \\
\hline 43 & 1.35 & 1.54 & -0.19 & 2,643 & 1.12 & 1.62 & -0.50 & 728 \\
\hline 44 & 1.28 & 1.51 & -0.23 & 2,672 & 0.93 & 1.52 & -0.59 & 753 \\
\hline 45 & 1.23 & 1.54 & -0.31 & 2,620 & 0.92 & 1.63 & -0.71 & 816 \\
\hline 46 & 1.14 & 1.52 & -0.38 & 2,467 & 0.84 & 1.68 & -0.84 & 742 \\
\hline total $n$ & & & & 54,973 & & & & 16,265 \\
\hline
\end{tabular}

Notes: Notes: Eastern Germany including Berlin. Source: Mikrozensus 2008. Authors' own calculations. 
Table 2: $\quad$ Average number of children and number of cases in each age group for different groups. Mikrozensus 2008.

\begin{tabular}{|c|c|c|c|c|c|c|c|c|}
\hline \multirow[b]{2}{*}{$\begin{array}{l}\text { age of } \\
\text { woman } \\
\text { in years }\end{array}$} & \multicolumn{4}{|c|}{ Turkish female migrants } & \multicolumn{4}{|c|}{ female Aussiedler } \\
\hline & $\begin{array}{l}\text { Own- } \\
\text { Children } \\
\text { Method }\end{array}$ & $\begin{array}{l}\text { reported } \\
\text { number of } \\
\text { kids }\end{array}$ & difference & $\mathrm{n}$ & $\begin{array}{l}\text { Own- } \\
\text { Children } \\
\text { Method }\end{array}$ & $\begin{array}{l}\text { reported } \\
\text { number } \\
\text { of kids }\end{array}$ & difference & $\mathrm{n}$ \\
\hline 18 & 0.00 & 0.00 & 0.00 & 16 & 0.03 & 0.06 & -0.03 & 74 \\
\hline 19 & 0.14 & 0.14 & 0.00 & 29 & 0.02 & 0.06 & -0.04 & 89 \\
\hline 20 & 0.17 & 0.17 & 0.00 & 23 & 0.11 & 0.14 & -0.03 & 119 \\
\hline 21 & 0.17 & 0.17 & 0.00 & 29 & 0.07 & 0.08 & -0.01 & 115 \\
\hline 22 & 0.57 & 0.58 & -0.01 & 37 & 0.16 & 0.16 & 0.00 & 124 \\
\hline 23 & 0.83 & 0.86 & -0.03 & 36 & 0.30 & 0.30 & 0.00 & 117 \\
\hline 24 & 0.87 & 0.92 & -0.05 & 38 & 0.30 & 0.30 & 0.00 & 119 \\
\hline 25 & 1.25 & 1.25 & 0.00 & 51 & 0.51 & 0.53 & -0.02 & 125 \\
\hline 26 & 1.43 & 1.32 & 0.11 & 60 & 0.70 & 0.72 & -0.02 & 135 \\
\hline 27 & 1.61 & 1.67 & -0.06 & 51 & 0.67 & 0.69 & -0.02 & 108 \\
\hline 28 & 1.66 & 1.66 & 0.00 & 61 & 1.03 & 1.07 & -0.04 & 120 \\
\hline 29 & 1.58 & 1.56 & 0.02 & 67 & 1.25 & 1.26 & -0.01 & 92 \\
\hline 30 & 1.82 & 1.75 & 0.07 & 60 & 1.23 & 1.29 & -0.06 & 113 \\
\hline 31 & 2.20 & 2.20 & 0.00 & 93 & 1.27 & 1.30 & -0.03 & 101 \\
\hline 32 & 2.05 & 2.01 & 0.04 & 83 & 1.36 & 1.38 & -0.02 & 88 \\
\hline 33 & 2.13 & 2.17 & -0.04 & 90 & 1.64 & 1.65 & -0.01 & 107 \\
\hline 34 & 2.33 & 2.32 & 0.01 & 101 & 1.66 & 1.69 & -0.03 & 82 \\
\hline 35 & 2.44 & 2.40 & 0.04 & 107 & 1.75 & 1.78 & -0.03 & 91 \\
\hline 36 & 2.35 & 2.42 & -0.07 & 105 & 1.58 & 1.60 & -0.02 & 90 \\
\hline 37 & 2.24 & 2.37 & -0.13 & 114 & 1.78 & 1.87 & -0.09 & 103 \\
\hline 38 & 2.30 & 2.33 & -0.03 & 126 & 1.61 & 1.71 & -0.10 & 83 \\
\hline 39 & 2.53 & 2.60 & -0.07 & 121 & 1.55 & 1.62 & -0.07 & 109 \\
\hline 40 & 2.20 & 2.34 & -0.14 & 109 & 1.56 & 1.71 & -0.15 & 125 \\
\hline 41 & 2.24 & 2.57 & -0.33 & 90 & 1.73 & 1.86 & -0.13 & 112 \\
\hline 42 & 2.38 & 2.81 & -0.43 & 114 & 1.64 & 2.00 & -0.36 & 108 \\
\hline 43 & 2.47 & 2.87 & -0.40 & 117 & 1.65 & 2.11 & -0.46 & 133 \\
\hline 44 & 2.02 & 2.61 & -0.59 & 95 & 1.51 & 2.07 & -0.56 & 142 \\
\hline 45 & 1.80 & 2.62 & -0.82 & 81 & 1.15 & 1.77 & -0.62 & 136 \\
\hline 46 & 1.95 & 2.63 & -0.68 & 60 & 1.27 & 1.95 & -0.68 & 133 \\
\hline total $n$ & & & & 2,164 & & & & 3,193 \\
\hline
\end{tabular}

Notes: Women with foreign ethnicity might reside in both eastern or western Germany (including Berlin). Aussiedler are ethnic German repatriates who migrated from the successive states of the former Soviet Union and other former eastern bloc states. Non-German women include women who migrated themselves ( $1^{\text {st }}$ and $1.5^{\text {th }}$ generation migrants). Source: Mikrozensus 2008. Authors' own calculations. 